\title{
Carbon neutral mine site accommodation village: Developing the model
}

\author{
David Goodfield, Martin Anda and Goen Ho \\ Murdoch University, Perth, Western Australia \\ E-mail:d.goodfield@murdoch.edu.au
}

\begin{abstract}
The imperative to reduce atmospheric carbon is well documented and one significant area of production is from the built form which is responsible for up to $40 \%$ of global energy consumption and $30 \%$ of the world's carbon emissions (UNEP, 2009). Over the full life cycle of buildings, which includes construction and demolition, $80-90 \%$ of this energy is used during the operational phase to heat, cool, ventilate, light and run appliances (ibid). The balance of $10-20 \%$ represents the embodied energy and is consumed during the building process of construction and production of the raw materials themselves (ibid). The embodied energy proportion varies considerably according to the life expectancy of the building. This proportion of the overall emissions will increase as the life span decreases and in the context of mine site village development is certainly on the higher side as most sites have a life span of less than 20 years. The need for the transport of goods and services, delivery of water and waste services to and from buildings adds further to account of emissions that the built form is responsible for and the total can be described as the carbon footprint. Measuring this and reducing it to a point of carbon neutrality is the overall aim of our research.
\end{abstract}

The term 'carbon neutral' has been defined largely by popular usage in the past (Murray and Dey, 2007). Even within scientific literature the academic definitions are few and varied, despite a raft of papers on life cycle analysis, input and output methods and tools for carbon accounting, especially when considering which emissions of the built form life cycle are actually to be included (Wiedmann and Minx, 2008). Murray and Dev (2007) discuss the terms 'carbon neutral' and 'carbon footprint' with several references on the subject. One such, Wiedmann and Minx (2008) concludes that a carbon footprint should only include $\mathrm{CO}_{2}$ and no other greenhouse gases (GHG) from indirect, upstream emissions, as well as direct onsite emissions. In contrast, and in the context of this paper, the calculation of the carbon footprint is regarded as comprising of all the carbon emissions from the complete life cycle of the mine site village that can reasonably be calculated, from a clear site for development through to the remediation of the site following removal or demolition. Determining which emissions can 'reasonably' be included and how they are calculated will determine the potential applicability of the model to mine site village development generally.

A specific case study has been secured of a recently constructed mine site village in the heart of the Western Australia's Pilbara region built to accommodate 142 staff with an anticipated occupancy rate of $80 \%$. This paper details the methodology employed to calculate the total carbon emissions, the carbon footprint of this purpose built village and how to reduce it effectively to a point where carbon neutrality can be claimed. A conceptual model has been developed for calculating the emissions and is represented schematically in the paper with explanation of its parts. Once the carbon account, the overall footprint, is known then the task of building a strategy for reduction can commence. This will include: reduction of the embodied energy of construction; implementation of operational energy efficiency measures; renewable energy system offsets; and accredited biomass and carbon offset of the remaining emissions.

In respect of operational energy measurement data has been provided from a similar sized village which highlighted the major energy consuming circuits and systems. Consequently, the Pilbara village has been designed by electrical engineers according to this data and once in full operation needs to be verified. To achieve this a metering and remote sensing system has been designed and installed on site to measure these circuits and systems, some detail of which follows in the methodology section of this paper. The system is expected to provide substantial information which, once analysed, will provide a basis upon which to redesign the power generation and distribution systems throughout the village and make a definite contribution to the overall operational energy reduction strategy.

Keywords: Carbon neutral, carbon footprint reduction, built environment, mine site village. 


\section{INTRODUCTION}

This paper describes the content and application of a generic model of how to reduce the carbon emissions from mine site village development and strategy to reduce it to a point that can reasonably be termed 'carbon neutral.' As there is no consistent globally acceptable definition of the term 'carbon neutral' (ACCC, 2011) some clarification is required if it is ultimately to be claimed. Generally the term means 'achieving net zero carbon emissions by balancing the total emissions attributable to a process [in this case the construction, operation, demolition and remediation of a mining village] with the offset of those emissions by using more sustainable energy efficient design and energy systems, plus carbon credits gained from accredited methods of sequestration (Murray and Dey, 2007). Carbon Neutral Ltd (CN) investigates carbon neutral claims at the highest levels and describes the meaning as 'a term commonly used to refer to an organisation or product or service that is responsible for zero greenhouse gas emissions for a specified period of time. The company also agrees that there is no accepted definition but acknowledges there are acceptable guidelines and programmes for certification (Carbon Neutral, 2011). The National Carbon Offset Standard provides clear guidelines in how to claim carbon neutrality based on Australian and internationally accepted standards and provides benchmarks for the claim (NCOS, 2009). It states that for an organisation to be carbon neutral it 'is generally accepted best practice to: measure its carbon footprint; reduce emissions; and offset any residual emissions' (ibid at 6). The normative references used are; ISO 14064 series concerning GHG quantification, reporting and verification; ISO 14040 to 14044:2006 concerning environmental management and LCA; The GHG Protocol (Kyoto) in force from 2005 -2012; and the National Greenhouse and Energy Reporting Act 2007 (NGER Act) and supporting legislation and documentation (NCOS, 2009: 6-8).

In order to avoid contravention of Australian Consumer Law under the Competition and Consumer Act, 2010 carbon related claims must not 'mislead or deceive' those relying on the information (ACCC, 2011:3) and is equally relevant in this research. With this in mind managing the carbon emissions of the mine site village under investigation requires that they are calculated at the outset with full disclosure of the methods and metrics used. The village carbon inventory will necessitate a full life cycle analysis (LCA) to include the embodied energy of construction of the village as well as its overall operational energy through to demolition and site remediation, "from cradle to grave."

The carbon accounting method described herein requires that a variety of tools need to be employed to make a reasonably accurate calculation of embodied and overall operational energy of the case study village. Operational energy is particularly difficult to calculate as some activities, essential to accessing and running the village, will occur 'from sources not owned or controlled' (ACCC, 2011: 10) by the village operators. The total value of emissions attributable to the village will influence the reduction strategy according to the needs of the various stakeholders: the building manufacturer, village infrastructure developer; village owner and operator. The solutions will fall into several categories, namely: modification of the current power generation plant; energy efficiency opportunities; renewable and sustainable energy options; and the purchase of appropriate accredited offset mechanisms. The ACCC is particularly concerned about the selling of offsets, partly due to the management of such sales often resulting in several trades of the same offset, and to the inaccurate accounting of the carbon reducing value of the offset itself.

Once the overall footprint of the village is calculated, following the NCOS guidelines, then the task of building a strategy can commence. This will include: reduction of the embodied energy of construction; implementation of operational energy efficiency measures; renewable energy system offsets; and accredited biomass and carbon offset of the remaining emissions until a point of carbon neutrality is achieved, each process measured by the mass of carbon they are reduced by.

Australian mining companies have publicly expressed their desire to demonstrate an ethical corporate responsibility, especially during these times of climate change awareness and primary source of carbon pollution. Global miners, Rio Tinto, BHP and Xtrata, all significantly represented in Australia, accept their responsibility to tackle climate change (Rio Tinto, 2011; BHP, 2010; Xtrata, 2011). Environmental consultants Sinclair Knight Merz indicate that mining companies are now giving serious consideration to ecological sustainability in mine site accommodation development, as well as mining per se, and report on one such investigation (SKM, 2008), however, to date little more has been published by others. The awardwinning report reveals no quantification of the overall carbon footprint other than indicating a reduction in water use of 50 per cent and energy use of 30 per cent per head. This paper and subsequent research intends to be more informative. 


\section{PROJECT AIMS AND CONCEPTUAL MODEL}

The aim of this paper is to describe the development of a conceptual model upon which the overall research will be founded and is represented in Figure 1 with detail following.

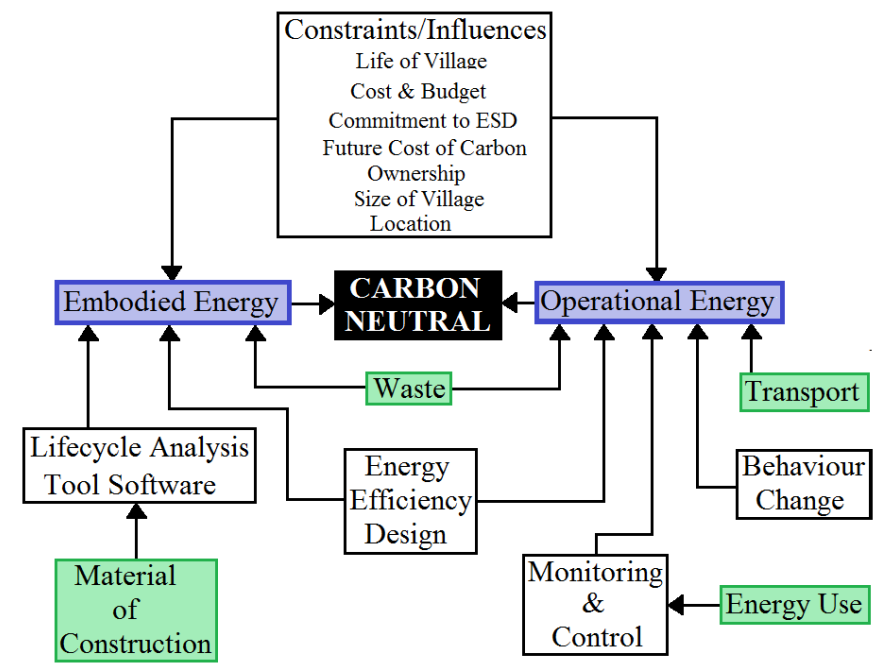

Figure 1. Conceptual model for calculating carbon neutrality in mine site villages

The research program as a whole is to define a carbon reduction strategy for mine site village development that will inform village designers, constructors, operators and owners how they can legitimately claim carbon neutrality and provide a template for future village development. Two inputs comprise the carbon footprint of the village as a whole: embodied energy and operational energy and these are calculated from the following:

2.1 Embodied energy emissions:

- of the materials of construction and village infrastructure.

- of the construction processes.

2.2 Operational energy emissions:

from the fugitive emissions of solid waste disposal.

- from stationary energy production (gas and diesel fuels).

- from transport fuels used in the construction and on-going use of the buildings.

- $\quad$ from the full water cycle.

- $\quad$ of transport to and from site (fly in-fly out).

- $\quad$ of transporting foodstuffs and supplies.

- of waste water treatment.

- $\quad$ of landscaping and on-site food production.

The components that will complete the embodied energy and operational energy calculations are broadly represented in Figure 1 by boxes with a grey shaded background. The methods of calculation and the potential solutions for reduction (in boxes with a white background) will be explained in the methods section below. Furthermore, there are several factors that will have an impact on the carbon footprint calculation and the methods used to reduce it, as represented at the head of Figure 1, namely:

- the anticipated life of the village. This will be determined at the outset by the mine owners according to their view of the viability of the resource and its profitability for the enterprise. However, commodity markets are volatile and will affect the potential life of the operation and the need for village accommodation.

- the budget for construction will affect the take up of the solutions to reduce the carbon footprint.

- the cost of paying for carbon emissions will fluctuate over time and impact on the need to reduce.

- $\quad$ if the camp is operated by those other than the mining company.

- larger villages are likely to have more scope for reduction of emissions, and lastly

- the village location is likely to affect the solutions. The solutions to reduce carbon in a coastal, grid connected village will be very different to those for an inland off-grid remote village. 
The carbon emission reduction process within the conceptual model is essentially comprised of five areas:

1. Energy efficient construction design;

2. Behaviour change to adopt new practices, infrastructure and sustainable systems;

3. Monitoring and control systems within a digitally integrated system ('smart grid');

4. Sustainable renewable energy systems;

5. Accredited biomass, soil carbon or forestry offsets.

\section{METHODS}

A 142-worker camp, servicing a gold mine in the Pilbara region of Western Australia, has been secured as a case study to apply the process of calculation of the carbon footprint of a typical mine site village. Agreements with both the mining company owners of the site and village construction company have been formalised facilitating access to install metering and monitoring equipment, data collection and transmission, and access to on site staff during the currency of the research. The conceptual model in figure 1 represents the basic components of the total carbon footprint calculation of this village and indicates where solutions can be applied to reduce it to a point of carbon neutrality. The model represents the research as a whole as mine site villages are essentially gated communities where inputs and outputs can be measured with a reasonable degree of accuracy. This paper broadly describes the method of calculation of the carbon footprint and the application of potential solutions that may be used to reduce it. Several processes are necessary to achieve this in order to reach a point of carbon neutrality.

3.1 Installation of metering and monitoring equipment - The village construction company, using experience from previous village sites, determined the significant areas of power and water use to meter and monitor. Pulse output meters for the bore water and desalinated water supplies were then installed with digital sensor and connection to a data logger. Power supplies to one 4-bed and one 2-bed accommodation module, the kitchen and mess, laundry, administration and gymnasium, were selected to monitor. The major circuits that supply these buildings were then selected for application of the monitoring equipment which for each circuit consisted of a current transformer to detect current, a digital sensor, and connection to a logger for data collection. Six data loggers in all to cover both water and power across the village, each connected to a radio transmitter. Data from the six transmitters will be collected by a similar receiver which in turn will be connected to the internet via a dedicated IP address. The data will, once the equipment is commissioned, be accessible online providing access to it as and when required.

3.2 Operational energy calculation - The collected data will provide load profiles and overall consumption of the monitored equipment. Although a large number of circuits will be monitored there will inevitably be gaps in the data. To fill these a level 2 energy audit, under AS 3598:2000, will be undertaken. The overall analysis will facilitate refinement of a strategy for operational energy reduction in terms of technology and materials of construction choice, as well as appliance modification or selection.

3.3 Embodied energy calculation - Life cycle analysis has a prominent role in all areas where carbon emissions are quantified and determining the boundaries of any calculation of carbon emissions attributable to the mine site village case study is fundamental as is the method adopted (Horne et al, 2009). This includes defining the system boundaries of where the responsibility for the emissions lays. Three methods will be used:

3.3.1 Carbon inventory analysis, which includes emissions from within the company's boundary and as a direct result of the company's activities. These are scope 1 and 2 emissions as defined by the Commonwealth Government (DCCEE, 2010) such as onsite energy use.

3.3.2 Life cycle analysis (LCA), a method supported by the International Energy Association outlined in AS/NZS ISO standard 14040:2006 Environmental Management- Life cycle assessment - principles and framework. The standard states that the assessment is conducted for impacts throughout a product's life, or "cradle to grave", including raw material acquisition, through to production, use and disposal.

3.3.3 Carbon profiling is a modification of LCA to include the emissions associated with land development itself according to the fuel consumed and its emissions factor when applied to a specific location (Hamilton et al, 2007).

3.4 Energy efficient design - Energy efficiencies can be applied in many ways, from simple technological solutions, such as increasing insulation and modifying lighting, to the more complex smart systems to monitor and control a building's thermal comfort. It has been estimated that energy savings of between 30 to $50 \%$ can be made without substantial expenditure (UNEP, 2007). 
3.5 Behaviour change - programs to achieve behaviour change in communities are now commonly practiced by utilities and governments and typically use a community based social marketing methodology (McKenzie-Mohr, 1999) for best results. Discussion and development of a methodology to introduce staff to new technologies and systems that might affect their amenity needs to follow the introduction of any technology or operational system change. Removal of any barriers to change is essential, not only to implement the change but to maintain it in a cost-effective and socially acceptable way (McKenzie-Mohr and Smith, 1999: 19). The significance of social acceptance is woven into the technology development (Oslislo, 2010: 2).

3.5 Assessment of renewable energy system offsets - the offset of a large proportion of the total carbon emissions of the village is likely to be by the introduction of renewable energy. Determination of the appropriate system or systems is a complex matter and at the outset requires collection of the data from the online system over a period of months, referred to previously in 3.1, and to the completion of the energy audit referred to in 3.2. The modelling tools HOMER and RETScreen ${ }^{\circledR}$, together with multicriteria and sensitivity analyses, will enable this assessment to be completed. However, for this to be effective and objective an appropriate balance between environmental, social and economic needs to made (Hardisty, 2010). Hardisty (2010: 66-77, 215-228) describes an objective approach to achieve this, which will be adopted, called Environmental and Economic Sustainability Assessment.

3.5.1 HOMER is a software tool for designing and analysing hybrid power systems and assists in the integration of variable resources such as wind and solar power (HOMER, 2010). RETScreen is software which assists in the analysis of the technical and financial viability of potential energy solutions (RETScreen, 2011).

3.6 Transport - fly in-fly out (FIFO) delivery, predominantly of staff, is clearly a huge contributor to carbon emissions. Although scope 3 emissions, under carbon accounting legislation NGERS (National Greenhouse Energy Reporting System, 2007) the airline is responsible for reporting its carbon emissions, it is clear that reduction in the number of flights would significantly reduce the carbon footprint of the mine site village. An investigation in how to make some reductions in this sector of emissions is therefore essential. Furthermore, there are several significant negative impacts of FIFO that cause employment and social disruption (Clifford, 2009).

3.7 Waste reduction is an essential element of the carbon emission reduction process both in the construction process and in waste disposal to landfill. 'The embodied energy and technical metabolism of construction waste have not been extensively applied' (Chong, 2008) and presents considerable scope in this sector to reduce emissions. Design and materials modification in the village construction process will reduce embodied energy used and reduce emissions accordingly. On site disposal of mine site village waste is a common practice resulting in fugitive emissions and an audit of waste to landfill will be carried out.

\section{OBSERVATIONS}

The collection of data, its application to a specific carbon reduction solution, carbon calculations, and delivery of a carbon neutral strategy are all a work in progress. The Pilbara case study has been secured and monitoring equipment installed on site ready for commissioning once the village is occupied and fully operational. Each area within the conceptual model in Figure 1 will be investigated or calculated as appropriate, and the embodied energy of the village, its infrastructure, and the energy required to operate it, will be calculated.

Calculation of the various sources of carbon emissions and a methodology for reduction has been described above. These have been estimated in respect of the case study as can be seen in table 1 below. Figures vary according to the boundaries of the calculation but the carbon footprint of the individual Australian lays somewhere between 18 and 27 tonnes of carbon dioxide (and GHG equivalents) per annum. (Garnaut, 2008), Estimated emissions of a single mine site worker at 12 tonnes per annum, with several areas unaccounted for, is significant.

\section{CONCLUSION}

Carbon neutrality across the built environment is clearly a desirable aim from both economic and environmental standpoints. This paper describes a conceptual model to achieve this across a broad set of carbon emission sources and the methods required. In order to establish acceptable metrics for carbon reduction modelling and establish a basis for its application to other forms of urban environments, specific measurement of the operational and embodied carbon needs to be made with some degree of accuracy. The conceptual model illustrated and detailed above will provide a sound basis for this to provide not only an 
overall village footprint but one that can be scaled according to location, size, and number of workers. To justify the claim for carbon neutrality all emissions from manufacture, installation and construction, maintenance, demolition and remediation need to be aggregated. Only then, and after energy efficiency measures and behaviour change measures have been put in place, can renewable energy and accredited carbon sequestration be calculated to offset the balance. Considering the number of mine site villages across the planet the potential for carbon reduction in this form of the built environment is potentially significant.

Table 1: Estimated carbon emissions for Pilbara mine site village case study.

\begin{tabular}{|c|c|c|c|c|c|c|}
\hline \multirow[t]{2}{*}{$\begin{array}{l}\text { Emission } \\
\text { Source }\end{array}$} & \multirow[t]{2}{*}{ Unit } & \multirow[t]{2}{*}{ No. } & $\begin{array}{l}\mathrm{CO}_{2-\mathrm{e}} \\
\text { tonnes/wor } \\
\text { ker/a }\end{array}$ & $\begin{array}{l}\text { Village } \mathrm{CO}_{2} \\
\text { Emissions } \\
\text { tonnes/a }\end{array}$ & \multirow[t]{2}{*}{ Comments } & \multirow[t]{2}{*}{ Basis of Estimate } \\
\hline & & & 1 worker & 142-person & & \\
\hline $\begin{array}{l}\text { Village } \\
\text { operational } \\
\text { Energy }\end{array}$ & GWhr/a & 1.85 & 3.03 & 430 & $\begin{array}{l}80 \% \text { natural gas } \\
20 \% \text { diesel }\end{array}$ & (DCCEE, 2010) \\
\hline $\begin{array}{l}\text { Embodied } \\
\text { Energy of } \\
\text { Materials of } \\
\text { Construction \& } \\
\text { Infrastructure }\end{array}$ & tonnes/a & & 0.42 & 60 & $\begin{array}{l}142 \text { workers } \\
40 \text { building } \\
\text { modules }\end{array}$ & $\begin{array}{l}\text { Modelling tool } \\
\left(\mathrm{eTool}^{\mathrm{TM}}\right) \\
\text { Assuming village has } 20 \\
\text { year lifespan }\end{array}$ \\
\hline $\begin{array}{l}\text { Emissions from } \\
\text { landfill (mixed } \\
\text { waste) }\end{array}$ & $\begin{array}{l}\text { tonnes/ } \\
\text { annum/ } \\
\text { person }\end{array}$ & 2.1 & 2.31 & 328 & $\begin{array}{l}\text { Waste of } \\
\text { unknown } \\
\text { composition }\end{array}$ & $\begin{array}{l}\text { 1. Annual waste/person } \\
\text { (ABS, 2010) } \\
\text { 2. } \mathrm{CO}_{2-\mathrm{e}} \text { landfill mixed } \\
\text { waste } \\
\text { (DCCEE, 2010: 70) }\end{array}$ \\
\hline Fly in-Fly out & $\begin{array}{l}\text { tonnes/ } \\
\text { annum/ } \\
\text { person }\end{array}$ & $\begin{array}{l}1 \text { return } \\
\text { flight/a }\end{array}$ & 6.24 & 886 & $\begin{array}{l}1200 \mathrm{~km} \text { return } \\
16 \text { return } \\
\text { flights/annum }\end{array}$ & $\begin{array}{l}\text { Short haul flight } \\
\text { (EPA, Vic:2009) }\end{array}$ \\
\hline & & TOTAL & 12.03 & 1704 & & \\
\hline
\end{tabular}

Excludes emissions from:

i. on site waste water treatment.

ii. transport of food and general supplies by road and air.

iii. on site transport specific to village operations.

\section{ACKNOWLEDGEMENTS}

Funding for this research is from Australian Research Council - Linkage Program (LP 0990631) and is supported by Commonwealth APA and Murdoch University award for excellence scholarships, financial and logistical support from Matricon Pty. Ltd., and financial support for a research assistant internship from WorleyParsons EcoNomics ${ }^{\mathrm{TM}}$.

\section{REFERENCES}

ABS (2010). Australian Bureau of Statistics, Measures of Australia's progress 2010, sourced online at http://www.abs.gov.au/ausstats/abs@.nsf/Lookup/by\%20Subject/1370.0 2010 Chapter Waste\%20per\% 20person\%20(6.6.3), accessed 12/9/11.

ACCC (2011). Carbon Claims and the Australian Consumer Law, Australian Competition and Consumer Commission sourced online at http://www.acc.gov.au/content/item.phtml?itemId=833279\&nodeId=9523cacf8d0e3e88725e89bb220aba $\mathrm{d} 5 \& \mathrm{fn}=$ Carbon $\% 20$ claims \%20and\%20the\%20ACL.pdf, accessed 8/8/2011.

Adoudi, M., and A. Taleveski (2010). Environmental Sustainability and Improved Quality of Life through Service Convergence Technologies, Proceedings of the $24^{\text {th }}$ International Conference on Advanced Information Networking and Applications, Dubai, pp.982-987.

Australian Government (2008). National Greenhouse and Energy Reporting Guidelines. Department of Climate Change, Canberra, ACT.

BERS Pro v.4.01(2011). Building Energy Rating software, Solar Logic Ltd., Qld.

BHP Billiton Group (2010). Letter to Task Group on Energy Efficiency, $17^{\text {th }}$ June 2010, sourced online at http://www.climatechange.gov.au/government/submissions/pm-task-group/ /media/submissions/pmtaskforce/papers/197-bhp-billiton.ashx, accessed 12/9/11. 
Goodfield et al. Carbon neutral mine site accommodation village...

Carbon Neutral (2011). A not-for profit Australian company that investigates carbon neutral claims and assists corporations and government bodies in reducing emissions, sourced online at http://www.carbonneutral.com.au/organisations/being-carbon-neutral.html, accessed 6/9/11.

Chong, W.K. (2008). Technical Metabolism and Building Designs, Proceedings of the International Conference on Waste Engineering and Management. Hong Kong, pp. c11- c17.

Clifford, S. (2009). The Effects of Fly-in/Fly-out Commute Arrangements and Extended Working Hours on the Stress, Lifestyle, Relationship and Health Characteristics of Western Australian Mining Employees and their Partners: Report of Research Findings, sourced online at http://www.uwa.edu.au/_data/assets/pdf file/0011/409988/FIFO_Report_c.pdf, accessed on 30/5/11.

DCCEE (2010). Department of Climate Change \& Energy Efficiency, National Greenhouse Accounts (NGA) Factors, Canberra, ACT.

EPA Vic (2009). Government of Victoria emissions management for flights, worksheet 3, sourced online at http://www.epa.vic.gov.au/climate-change/carbon-management/Worksheet 3-Flights.pdf, accessed $11 / 5 / 11$.

eTool (2011). Analysis software for sustainable design, sourced online at http://etool.net.au/software

Garnaut, R. (2008). The Garnaut Climate Change Review, final report pp.154, Cambridge University Press, UK.

Hardisty, P.E. (2010). Environmental and Economic Sustainability, CRC Press, Florida, USA.

Hamilton, C., J. Kellett, and X. Yuan (2007). Carbon profiling: an analysis of methods for establishing the local emissions baseline. School of Natural Built Environments, University of South Australia \& Centre for Design, RMIT, Melbourne.

HOMER (2010). HOMER v.2.81®, Homer Energy, Optimising Clean Power Everywhere, Energy modelling software for hybrid renewable energy systems, Boulder, USA, sourced online at http://homerenergy.com, accessed 10/8/11.

Horne, R., T. Grant, and K.Verghesse (2009). Life Cycle Assessment: Principles, Practice and Prospects, CSIRO Publishing, Collingwood, Victoria.

Kohn, M.M, E. Chang, A.P. Karduck, and A. Talevski (2010). Smart camp: Environmental Sustainability through Intelligent Automation Technologies, Proceedings of the $24^{\text {th }}$ International Conference on Advanced Information Networking and Applications, Dubai, pp. 286-292.

McKenzie-Mohr, D., and W. Smith (1999). Fostering Sustainable Behaviour: An Introduction to Social Marketing, New Society Publishers, Gabriola Island, B.C., Canada, pp.19-45.

Murray, J., and C, Dey (2007). Carbon neutral - sense and sensibility. Centre for Integrated Sustainability Analysis, University of Sydney, NSW, accessed online at http://www.isa.org.usyd.edu.au/publications/CarbonNeutral.pdf, at p.7, accessed 7/9/11.

NCOS (2009). National Carbon Offset Standard, Department of Climate Change \& Energy Efficiency, Government of Australia, sourced online at http://www.climatechange.gov.au/government/initiatives/ /media/publications/carbonaccounting/revised-NCOS-standard-2010-pdf.ashx, accessed on 2/6/10.

RETScreen (2011). RETScreen v.4 ${ }^{\mathrm{TM}}$ Clean energy project analysis software, sourced online at http://www.retscreen.net/ang/home.php

Rio Tinto (2011). Company website on climate change sourced at http://www.riotinto.com/ourapproach/17214_climate_change.asp, accessed 12/9/11

SKM (2008). Improving the sustainability of mine camps, Sinclair Knight Merz magazine, sourced online at http://www.skmconsulting.com/Knowledge-and-Insights/Achieve-Articles/2009/ImprovingSustainability-of-Mine-Camps.aspx, accessed 2/12/09.

UNEP-SBCI (2009). Buildings and climate change: Summary for decision-makers, United Nations Environment Program Sustainable Building Climate Initiative.

UNEP (2009). Common carbon metric: for measuring energy use \& reporting greenhouse gas emissions from building operations, a United Nations Environment Program Sustainable Building Climate Initiative.

Wiedmann, T., and J. Minx (2008). A Definition of Carbon Footprint, in C. C. Pertsova (ed.) Ecological Economics Research Trends, pp. 1-11, Nova Science Publishers, Hauppauge, NY, USA, sourced online at http://www.censa.org.uk/docs/ISA-UK_Report_07-01_carbon_footprint.pdf, accessed 7/9/11.

WRI (2011). World Resource Institute calculator for Greenhouse Gas Protocol Initiative, sourced online at http://www.ghgprotocol.org/calculation-tools/all-tools, accessed 12/5/11.

Xtrata (2011). Climate change strategy \& management, sourced online at http://www.xstrata.com/sustainability/environment/climatechange/climatestrategy/, accessed 12/9/11. 